\title{
Job-Related Stress among Public Junior Secondary School Teachers in Abuja, Nigeria
}

\author{
Ukonu, Ifeanyichukwu Ojeka \\ Department of Industrial Relations and Personnel Management \\ Michael Okpara University of Agriculture, Umudike, Abia State, Nigeria
}

Serieke-Dickson, Rachel (PhD) Department of Business Administration

Faculty of Management Sciences; Niger delta, Wiberforce island, Bayelsa state, Nigeria

\section{Edeoga, Georgina}

Department of Industrial Relations and Personnel Management

Michael Okpara University of Agriculture, Umudike, Abia State, Nigeria

Received: Sep. 6, 2018 Accepted: Jan. 9, 2019 Online published: Jan. 22, 2019

doi:10.5296/ijhrs.v9i1.13589 URL: https://doi.org/10.5296/ijhrs.v9i1.13589

\begin{abstract}
In time past, teaching profession was presumed to be stress free. Conversely, stress is gradually becoming endemic in various professions. However, recent studies have shown an exponential increase in the number of educators reporting that stress is affecting their work. Hence, this study seeks to examine causes, signs, symptoms and consequences of job stress among Junior Secondary School teachers in Abuja. This qualitative study used interview to elicit information from a focused group. Thematic content analysis was used to analyse data generated. The findings showed that teachers' stress emanated from external and internal work environments which have moderating and mediating effect on the level of stress an individual feel in carrying out his/her work. Moreover, the consequences of the identified stressors were psychological, behavioural and physiological. Furthermore, the study suggests preventive and interventional measures which can aid to reduce the negative effects of stress on teachers.
\end{abstract}

Keywords: job stress, teachers' stress, job performance, secondary school, work environment 


\section{Introduction}

Teaching is asserted to be a primogenital profession among others and invariably a noble one. It is believed that all other professions take their roots and nourishment from the said profession (Hanif, 2004). Thus, the profession can be demanding and involving highly intellectual activities. Amidst these activities, stress may be inevitable. Consequently, teachers' stress has been a subject of research for many decades (Dlamini and Okeke et al, 2014; Pandey, 2015). Traditionally, teaching profession was believed to be a low stress occupation (French, et al 1982 as cited in Parray, et al 2016). However, in the past decades, researchers have shown that all over the world, teaching profession is a stressful occupation (Manabete et al, 2016, Precey, 2015, Dlamini and Okeke, et al, 2014, Nwosu and Ayodele, 2011; Alan et al, 2010), at all levels from the elementary to university level (Parray, et al, 2016). As such, researchers have gradually become more interested in examining stress in the teaching profession. Moreover, reports have shown that level of teachers' stress has increased both nationally and internationally (McIntyre, 2015).

Empirically, Health Safety Executive (HSE) statistics have shown that for up to five consecutive years; teaching has unswervingly been one of the three occupations experiencing the highest levels of work related stress (National Union of Teachers, 2016). To buttress this fact, out of the 80 occupations studied by Sir Gary Cooper (2015), teaching profession was asserted to be among the three occupations experiencing the highest level of work-related stress alongside uniform and health services (Wiggins, 2015, National Union of Teachers, 2016). National Union of Teachers report (2016) stated that studies into the extent of work-related stress in Britain have consistently found that teachers are amongst the most stressed workers in Britain.

Furthermore, Health Safety Executive (HSE) research has found that one in five people: an estimate of 5 million workers are either 'very' or 'extremely' stressed at work, and that stress, anxiety and depression generally lead to more than thirteen and a half million lost working days each year and it costs society about $£ 3.7$ billion every year (at 1995/6 prices) (Cartwright and Cooper 2002). This figure includes those in teaching profession. In the same vein, the International Labour Organisation has estimated that the cost of stress to the British economy amounts to over ten per cent of its Gross National Product (GNP). Likewise, Studies across the globe revealed that teachers in the developed countries such as America (Will, 2017), Europe (European Education International/European Trade Union Committee on Education 2002) and Britain (Precey, 2015) are experiencing stress. In our locale, teachers are experiencing stress (Ekundayo and Kolawole, 2013).

Studies have shown that there are various causes of stress among teachers (Alan, et al, 2010). According to Will (2017) a survey carried out by the American Federation of Teachers of 5,000 educators revealed a broad band of complaints about their job that leads to stress. This ranges from unfunded mandates such as the Common Core curriculum standards and high-stakes achievement tests, as well as negative headlines and finger-pointing about failing schools and the black-white achievement gap. Meanwhile, in Britain the major issue is that of unnecessary workload (Precey, 2015). In a study on Stress among Secondary School 
Teachers in Ekiti State, Nigeria, Ekundayo and Kolawole, (2013), revealed that there is stress in the teaching profession arising from economic problems, work overload, late payment of salary among others. Thus, we can say that the bedrock on which stress at job lies stems from pressure from both the external and internal work environment, ability to balance the activities from both ends and be optimal in ones' performance at the job.

Assertively, stress in itself is not a disease but its aftermath can disarticulate the normal body equilibrium which might lead to diseases (Manjula, 2012). Studies have shown that Stress within the confinement of an individual's comfort zone can help the individual perform under pressure; motivate him/her to perform optimally (Sanders, 2013, Segal, et al, 2016, Hellriegel and Slocum, 2010). But when stress becomes prodigious or prolonged, it can damage an individual's mood and relationships, and lead to a host of serious mental and physical health problems (Ghkadmin, 2015) and can affect performance. According to the Office for National Statistics, there has been nearly a 50 per cent increase in the number of teachers committing suicide between 2010 (42 teachers) and 2012 (62 teachers) whose link is likely traceable to stress (National Union of Teachers, 2016). McDevitt (2011) argued that the number of teachers committing suicide in Britain each year has almost doubled as a result of failing to cope with the stress of the job.

To accomplish quality education for sustainable development, there is need to ensure that teachers who are the fundamental inculcators of knowledge be well motivated, healthy and satisfied with their job for excellent performance (Wangui and Ombui, et al 2016) with stressors reduced to the barest minimum; as studies have shown that, some stressors could lead to stress, ill health, poor performance and eventually high teacher turnover (Wangui, et al, 2016, Borg, 2010). A question that would easily come to one's mind is how teaching once considered as a low stress profession crawled to a stressful profession. Therefore, this study seeks to highlight causes, sign, symptoms and consequences of stress among public junior secondary school teachers in FCT Abuja. Secondly, the study seeks to determine its psychological, behavioural and physiological effect on teachers.

\subsection{Objectives of the Study}

This study seeks to determine the:

i. causes of job stress among Junior secondary school teachers in Abuja

ii. signs and symptoms of stress among teachers

iii. consequences of stress on teachers

\section{Review of Related Literature}

\subsection{Stress}

Various definitions of stress have been formulated since the concept was first named and described by Hans Selye in 1960. These definitions seem to have failed to capture what is perceived as the essence of the concept by a major proportion of stress researchers (ILO content manager, 2011). For the purpose of this study we will consider some of the 
definitions.

Stress is a psychological and physiological response to events that upset our personal balance (Manjula, 2012), and defence mechanism for dealing with any factor, which alters the normal biological processes of the body (McEvoy, 2011). It also refers to a person's adaptive response to a stimulus that places excessive psychological or physical demands on him or her (Griffin and Moorhead, 2010). Omolara (2008) in line with the Griffin and Moorhead (2010) definition of the concept, described stress as the adverse psychological and physical reactions that occur in an individual as a result of their being unable to cope with the demands being made on them. In other words, stress can be as a result of an individual's inability to cope with some factors in his/her work environment. Cole (2005) however argued that stress is triggered by external problems faced by individuals, as well as the way they cope or fail to cope with those problems. Moss (2008), defined stress as any objective condition or any change in the work environment that is perceived as potentially harmful, threatening, challenging, or frustrating, or any set of circumstances related to work that requires change in the individual's on-going life pattern. This definition did not take into cognisance the psychological factors that could lead to stress. Hellriegel and Slocum (2010) defined stress as the excitement, feeling of anxiety or physical tension that occurs when demands placed on an individual are thought to exceed his ability of how to adjust

Most of these definitions focused mainly on the conditions of work and work environment. It did not consider the individual's personality traits, physiological/psychological factors that could lead to stress. As such, stress is an individual's physiological and emotional response to stimuli that place physical or physiological demands on the individual and create uncertainty and lack of personal control when important outcomes are at stake (Samson, 2003 as cited in Jehangir, et al 2011). Also, these definitions show an author's perception about stress. Therefore, to conjure up the definition of stress, one has to encompass the physiological, behavioural, emotional and psychological factors that could lead to stress especially in the workplace. Thus, stress can be seen as the adverse psychological, physiological, behavioural and physical reactions that occur in an individual thereby causing a distortion of their stable state of equilibrium as a result of their inability unable to cope with the demands made on them. Hence, it is important to define stress putting into consideration, the individual's personality type, the environment and the situation.

\subsection{Job Stress}

Job stress can be referred to as the harmful physical and emotional responses that occur when the requirements of the job do not match the capabilities, resources, or needs of the worker. This can lead to poor health and even injury (National Institute for Occupational Safety and Health, 2014). Olusegun and Oluwasayo et al (2014) argued that Job stress is commonly acknowledged to be a critical issue for managers of organisations. They further argued that job stressors tend to contribute to organisational inefficiency. However, it has be reported that job-related stress often arises from unexpected responsibilities and pressures that do not align with a person's knowledge, skills, or expectations, inhibiting one's ability to cope (Jitendar et $a l$, 2016). It can increase when workers do not feel supported by supervisors or colleagues, or 
feel as if they have little control over work processes (World Health Organization, 2015). In recent times, the nature of work and the workplace is changing. Some of the changes are due to technological advancement, diversity in the workplace, inability of organisations to sustain their business thereby adopting some strategies like merger and acquisition, downsizing and right sizing and other measures which might pose a threat to employees' position in an organisation. Perhaps now more than ever before, job stress poses a threat to the health of workers and, in turn, to the health of organisations (NIOSH, Ukonu and Tafamel, 2011). Studies such as Olusegun and Oluwasayo, et al (2014), have opined that more than half of all Nigerian workers feel the pressure of job related stress.

Marrying the definitions together, an interface is expounded in the fact that stress is pervasive and inevitable as one carries out his/her duties in an organisation. In addition, reaction to stress varies from individual. The inevitability of stress can be deduced from past-paced dynamic nature of the work environment, and differences in individuals' physiological and psychological state. Scholars have argued that job stress on the long run might alter an individual's physiological, emotional, behavioural or perceptual and intellectual wellbeing (Olusegun and Oluwasayo, et al, 2014; Health and Safety Executive, 2014). The bottom line is the fact that job stress in one way or the other has consequences on an individual facing it and it varies from person to person.
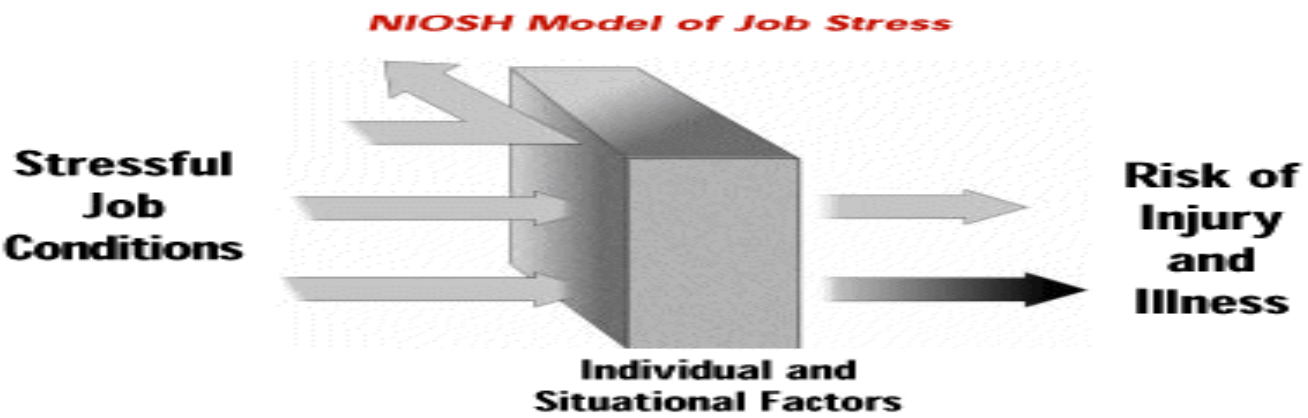

(Source: National Institute for Occupational Safety and Health (NIOSH) Stress at Work DHHS (NIOSH) Publication Number 99-101 Retrieved on 02/09/2016 from http://wwwn.cdc.gov/pubs/niosh.aspx)

\subsection{Teachers' Stress}

Teaching is asserted to be one of the most stressful professions (Manabete et al, 2016, Precey, 2015, Nwosu and Ayodele, 2011, Sprenger, 2011) across the globe. Some researchers have noted that the professional activity of teachers is one of the most stressful social activities among the jobs that are characterised by a large number of stress factors (for example: Barabanshchikova, et al 2014). Sprenger (2011) conducted a study on stress and coping behaviours among primary school teachers and the result showed that $100 \%$ of the study population believe that teaching profession is stressful while $72 \%$ asserted that the profession was extremely or very stressful. The survey by Teachers Assurance shows that $76 \%$ of teachers believe that workplace stress is making them ill, with $56 \%$ believing they would do a better job if they were less stressed. In addition, $40 \%$ feel they argue more with their partners 
and friends as a result of the pressures they face and $83 \%$ said they feel constantly exhausted because of work (Bousted, 2013). Teaching as a profession does not exist in vacuum or limited to the classroom. It entails interactions between individuals be it students, colleagues, supervisors, subordinates or superordinate and their environment. These interactions when perceived as straining or surpassing the adaptive capacities of the individuals which invariably tampers with their well-being leads to stress.

Thus, teacher stress refers to a response to negative state such as anger, or depression by a teacher. This is usually accompanied by potentially pathogenic, physiological or biochemical changes resulting from aspects of the teacher's job and mediated by the perception that the demands made upon the teacher constitutes a threat to his/her self-esteemed or well-being and by coping mechanisms activated to reduce the perceived threat (Kyriacou, 2001, Alan, et $a l, 2010$, Reddy and Anuradha, 2013). Although, this definition is widely accepted, it did not capture endogenous and exogenous factors that can lead to stress and an individual's personality type for example type A or B. The definition did not differentiate between role related stress and task related stress. Some authors have argued that stress response can be induced by both endogenous and exogenous factors (Manjula, 2012).

Exogenous (external) factors emanate from outside such as life changes, work relationship difficulties, economic problems, financial problems, work-family conflict, daily hassles (Merajver-Kurlat, 2009), organisational factors such as poor physical working conditions, work overload or time pressures (Hamlett, 2016). Often, one's role in the organisation and the ambiguity associated with the job resulting from inadequate information concerning expectations, authority and responsibilities to perform one's role as well as the conflict that arises from the demands placed on the individual by superiors, peers and subordinates could also result in stress (Olusegun and Oluwasayo et al, 2014). As documented in the ASSET model, stressors include the impact a person's working life has on their life outside of work (work-life balance), the amount of satisfaction people derive from their work, the degree of control and autonomy people have in the work place, and the levels of commitment in the work place both from the employee to the organisation and from the organisation to the employee (Johnson, 2005).

In addition, Endogenous factors are peculiar to an individual, others are sex, education and a personality that is deemed Type A or inherently stressful or Type B. Type A individuals are extremely competitive, hostile, impatient, hasty, restless, very alert, hard driving, and with explosive speech (Olusegun and Oluwasayo et al, 2014, Naidoo, et al, 2013). On the other hand, Type B personality are easy going, take difficulties in their stride, spend time on what they do and maintain a careful balance between events and actions demanding their energy (Naidoo, et al, 2013). Fisher (2011) states that Type ' $A$ ' teachers are more aggressive, and would consider themselves to be "perfectionists."

\subsection{Causes of Teacher Stress}

Several researches have been conducted on potential causes of stress among teachers (Alan, et al, 2010). Johnson et al (2005) listed Cooper and Marshall's five sources of stress, with examples of the components of these sources given for each, are: first, Intrinsic to the job, 
including factors such as poor physical working conditions, work overload or time pressures; secondly, role in the organisation, including role ambiguity and role conflict; thirdly, career development, including lack of job security and under/over promotion; fourthly, relationships at work, including poor relationships with your boss or colleagues, an extreme component of which is bullying in the workplace; and fifthly, organisational structure and climate, including little involvement in decision-making and office politics.

Education International/European Trade Union Committee for Education Stress Report conducted a study on stress across all Central and Eastern European member organisations of Education International on, "The cause of stress for teachers, its effects, and suggested approaches to reduce it". Their study revealed the following causes of stress. Professional skills including: New teaching methods, Changes in curriculum and courses, Adaptation to changes in information and communication technology, inadequate training and continuing education. Second on their list was Economic pressures consisting inadequate salary, Job insecurity. Thirdly, was Students issues characterised by Drugs, violence, aggression Increased class size per teacher Lack of pupil motivation, attention and interest Decrease in discipline Grading and assessment, and Target setting and meeting targets. Fourthly, Difficult parent/teacher relations New demands regarding roles of the teacher, Responsibility for overall student welfare, Decreased parent participation. Fifthly, Poor planning and programming, Constant restructuring, Frequent reforms in the vocational educational system, Working alone and the transition to team work, Lack of personnel and poor allocation, Strong administrative hierarchy with a lack of support, Insufficient financial resources. Sixthly, Social and personal pressures, Teachers' own ambitions, Concerns about the quality of education, Lack of coherence between personal goals and professional obligations, Social position - no recognition or acknowledgement, Lack of public esteem, Society demands on the duty of a teacher in a child's upbringing. Last and not the least was the school as a stressful workplace, Excessive workload and hours of work, lack of time, Lack of control and autonomy, Environmental noise, poor ventilation, Lack of solidarity and morale, Problems with hygiene and security, Excessive paperwork and administrative duties, Discrimination and workplace bullying, Lack of sufficient and up to date teaching material, equipment, and class rooms, Solitude and isolation. It is evident from the above study that most of the causes of stress depend on the organisation of work followed by societal and personal challenges which are related to a teacher's job.

\subsection{Signs and Symptoms of Stress}

Studies have elucidated some signs and symptoms of job related stress. These include: Feeling anxious, irritable, or depressed; apathy, loss of interest in work; sleeping problem, fatigue, trouble concentrating, muscle tension or heads, stomach problems, social withdrawal, loss of sex drive, use of alcohol or drugs to cope (Segal et al, 2016) others are: headache, sleep disturbances, difficulty in concentration, stomach upset, job dissatisfaction, Low morale (International Labour Organisation ILO, 2012). Health and Safety Executive (2014) listed some signs and symptoms of stress in an individual. There are emotional, mental and changes from one's normal behaviour. Emotional symptoms are: negative or depressive feeling; disappointment with yourself; increased emotional reactions - more tearful or sensitive or 
aggressive; loneliness, withdrawn; loss of motivation, commitment and confidence, and mood swings (not behavioural). Mental symptoms are: confusion, indecision; inability to concentrate; and poor memory. Further more stress can be seen in irrational changes in behaviour such as changes in eating habits, increased smoking, drinking or drug taking 'to cope'; mood swings affecting your behaviour, Changes in sleep patterns; twitchy, nervous behaviour, changes in attendance such as arriving later or taking more time off.

\subsection{Consequences of Job Stress on Secondary School Teachers}

It's been argued that there are three main consequences of job related stress namely: physiological, psychological and behavioural consequences.

\section{- Physiological consequences}

Physiological implication of stress affects educator's physical health; the most common being headaches, high blood pressure and heart disease. Studies have listed other consequences to include immune system problems, musculosketal system problems like backaches, and gastrointestinal problem (American Institute on Stress AIS).

\section{- Psychological consequences}

Psychologically, stress negatively affects the way the brain and the nervous system operate while critical cognitive processes are the ones that normally help people manage conflict-become impaired, resulting in an "inner noise" (Nagel and Brown, 2003) Stress from "inner noise" leads to memory loss, the inability to solve problems, and the absence of creativity, among critical coping mechanisms (Cherry, 2018). Other psychological consequences of stress can result in emotional instability, moodiness which can impact on reaction to learners and colleagues. Nervousness and tension can eventually result in the lack of concentration and will impact on work performance. Others are: chronic illness, depression and burnout (Cherry and Brown, 2018).

\section{- Behavioural consequences}

Stress may pose a threat to an individual and people around due to transferred aggression. One of such behaviour is drug abuse resulting to consumption of psycho active substance, consumption of alcohol or smoking. Research has shown that smokers are more likely to smoke more under stress, also consumption of alcohol and drug abuse may also increase under stress (Palmer et al. 2006; Uchendu and Ukonu, 2016). Other possible behavioural consequences are accident proneness, violence and appetite disorders (Moorhead and Griffin 2004). Naidoo, et al (2016) posit that Organisational stressors frequently create job dissatisfaction. This could lead to absenteeism and lackadaisical attitude and apathy towards work as a teacher.

\section{Methodology}

This study adopted a qualitative research design. Two schools were studied. They were group A- Junior Secondary School, Phase III and group B- Junior Secondary School, Kubwa (2016-2017). Data was obtained through secondary data and interview with consented teachers through a focused group. The leader of each group gave a summary of causes, signs, symptoms and consequences of stress. 
- The first question was to state levels of stress as a teacher. The responses were very stressful, quite stressful, often stressful and never stressful.

- The question on causes of stress was adopted from based on the study done by Education International/European Trade Union Committee for Education Stress Report conducted a study on stress across all Central and Eastern European member organisations of Education International on, "The cause of stress for teachers, its effects, and suggested approaches to reduce it".

- The secondary data was obtained through administrative records of the various schools studied.

- Primary data was analysed using Thematic Content Analysis for interview questions while secondary data was analysed using frequencies, percentages

\section{Results and Findings}

It was shown in table 1, that there were more females in both schools studied. The ratio of male to female is 1:1.6 and 1:3.2 in A and B respectively. In group A 88.3\% of the teachers are married while $81.0 \%$ in Group B are married. Notably, there were no significant differences in the sex distribution and marital status in both schools.

From table 2, school A had averagely 80 students per class and School B 75 students per class. More than $95 \%$ believe there is stress in teaching profession at the junior secondary level. Both schools asserted that language teachers have the highest workload due to the fact that only three teachers taking native languages in the whole and only one French teacher as at the time of writing this report. Only $4.8 \%$ and $4.4 \%$ from A and B respectively repudiated the significance of stress as they carried out the jobs as teachers.

Table 1. Demographic Characteristics of Teachers in the study

\begin{tabular}{|c|c|c|c|c|c|c|}
\hline & \multicolumn{2}{|c|}{$\begin{array}{c}\text { School A } \\
(\mathrm{n}=60)\end{array}$} & & \multirow[t]{3}{*}{$\begin{array}{c}\text { School B } \\
(n=63)\end{array}$} & \multirow[t]{3}{*}{$X^{2}$} & \multirow[t]{3}{*}{ Fisher's exact $P$} \\
\hline & $\mathbf{N}$ & & $\mathbf{N}$ & & & \\
\hline & $\%$ & & $\%$ & & & \\
\hline \multicolumn{7}{|l|}{ Sex } \\
\hline Male & 23 & 38.3 & 15 & 23.8 & & \\
\hline Female & 37 & 61.7 & 48 & 76.2 & 3.04 & 0.118 \\
\hline \multicolumn{7}{|c|}{ Marital status } \\
\hline Single & 7 & 11.7 & 12 & 19.0 & & \\
\hline Married & 53 & 88.3 & 51 & 81.0 & 1.28 & 0.322 \\
\hline
\end{tabular}

$\mathrm{N}$ - Total number of teachers 


\section{Ml Macrothink}

International Journal of Human Resource Studies

ISSN 2162-3058

2019, Vol. 9, No. 1

Table 2. Distribution of average number of students per class and total number of classes at the different classes and perception on levels of stress

\begin{tabular}{lll}
\hline Variable & School A & School B \\
\hline Average/class & 80 & 75 \\
Number of classes in Jss 1 (Frequency) & 8 & 10 \\
Number of classes in Jss 2 (Frequency) & 8 & 10 \\
Number of classes in Jss 3 (Frequency) & 8 & 10 \\
Level of stress & & \\
Very stressful (\%) & 30.7 & 33.2 \\
Quite stressful (\%) & 44.2 & 45.9 \\
Often stressful (\%) & 20.3 & 16.5 \\
Never stressful (\%) & 4.8 & 4.4 \\
\hline
\end{tabular}

Table 3. Causes, Effects and Consequences of Job Stress among secondary school teachers

\begin{tabular}{|c|c|c|c|}
\hline Cause of stress among teachers & Rating & Effects of stress & Consequences \\
\hline $\begin{array}{l}\text { Economic factors, poor salary } \\
\text { and high living standard }\end{array}$ & 2 & $\begin{array}{l}\text { Headache, high blood pressure. } \\
\text { Mood swing }\end{array}$ & $\begin{array}{l}\text { Physiological, } \\
\text { psychological }\end{array}$ \\
\hline $\begin{array}{l}\text { Environmental factors (poor } \\
\text { hygiene) }\end{array}$ & 8 & $\begin{array}{l}\text { Running stomach, toilet /bacterial } \\
\text { infection, vomiting, loss of appetite }\end{array}$ & $\begin{array}{l}\text { Physiological, } \\
\text { Behavioural }\end{array}$ \\
\hline Professional skills & 5 & Nervousness, loss of appetite & Behavioural \\
\hline $\begin{array}{l}\text { Excessive Work load and } \\
\text { large class size per teacher }\end{array}$ & 1 & $\begin{array}{l}\text { Back pain, chest pain, headache, } \\
\text { high blood pressure, Nausea, ulcer, } \\
\text { muscular pain, tensed, loss of sex } \\
\text { drive, fatigue, sleep problems, } \\
\text { shouting, }\end{array}$ & $\begin{array}{l}\text { Physiological, } \\
\text { psychological, } \\
\text { Behavioural }\end{array}$ \\
\hline Parent/teachers relationship & 6 & Headache, anger, depressed & $\begin{array}{l}\text { Physiological, } \\
\text { psychological }\end{array}$ \\
\hline $\begin{array}{l}\begin{array}{l}\text { Government policies } \\
\text { programmes }\end{array} \\
\end{array}$ & 3 & $\begin{array}{l}\text { Angry, irritable, low morale, lack of } \\
\text { concentration, lack of job } \\
\text { satisfaction }\end{array}$ & $\begin{array}{l}\text { Psychological, } \\
\text { Behavioural }\end{array}$ \\
\hline Work-life pressures & 7 & $\begin{array}{lr}\text { Fear, anxiety, loss } & \text { of } \\
\text { self-confidence, loss of sex } & \text { drive, } \\
\text { psycho-social pressure, } & \text { sleep } \\
\text { problem, emotional problem } & \end{array}$ & $\begin{array}{l}\text { Psychological, } \\
\text { Behavioural }\end{array}$ \\
\hline $\begin{array}{l}\text { Administrative pressures, lack } \\
\text { of autonomy and Inspection }\end{array}$ & 4 & Anxiety, loss of appetite & Psychological \\
\hline
\end{tabular}

Table 3 is a Thematic Content Analysis showing causes, effects and consequences of job stress on teachers. There were eight themes. The ratings on the average was documented.

\section{Causes of Stress among Teachers}

Teachers were asked the causes of stress among them. Table 3 above gave a summary of their response based on the study done by Education International/European Trade Union 
Committee for Education Stress Report conducted a study on stress across all Central and Eastern European member organisations of Education International on, "The cause of stress for teachers, its effects, and suggested approaches to reduce it". Highest on the list was excessive workload and class size per teacher, followed by economic factors, government policies and programmes, administrative pressures, professionalism, parent/teachers relationship, work-life pressures and environmental factors.

\subsection{Workload and Large Class Size per Teacher}

Large class sizes- Averagely, the school under study had 75-80 students per class [see table 2]. This implies increased class size per teacher. The teachers complained of handling the students especially as the classrooms made for 40 students is made to accommodate $75-80$ students. On grading and assessment, each teacher is expected to do a continuous assessment of each student ranging from promptness to school, neatness, and mark their notes at end of topic and at the end of the term mark and record the results. Also, due to the largeness of the class and inadequate space for the students, the first few minutes of the study time is channelled to bringing the students to order in other to commence lessons. Important to note is that the classrooms are so crowded leading to Environmental noise, poor ventilation and congested classrooms making the classroom not conducive for adequate learning. Sometimes the teachers have to shout and scream at the students to arrest their attention. Discipline is presumed to be on the decrease, violence, aggression on the increase resulting to poor student behaviour. The interview showed that language Teachers have the highest stress as one teacher per language is expected to take one arm.

\subsection{Economic Factors, Poor Salary and High Living Standard in Abuja}

Teachers in this study believe their salary is poor compared to the work they do. Due to high cost of living in Abuja, they feel stressed up as their salary cannot meet their basic financial obligations such as paying house rent, transportation to and fro school, feeding their dependent relatives and other relevant basic needs. Some of the teachers interviewed have to borrow from their Cooperative (local contributory association) to meet their basic needs.

\subsection{Government Programmes and Policies}

Incessant changes on extant rules, programmes, policies, restructuring and reforms in educational system without recourse to major stakeholders (teaching staff) have left most teachers confused as to what to do or not to do as they carry out their duties. They opined that as they are trying to adapt to a particular programme or policy a new one completely deviant from the previous one is introduced. Cut down on subsidy on education has affected the supply of working materials needed for effective teaching. Some of the teachers have had course to improvise. Some of the reforms involved merging of subjects such as basic technology, basic science, and computer science as a single subject forcing the teachers of the various subjects not to impact into the students all they need to know at a particular class.

\subsection{Administrative Pressures, Lack of Autonomy and Inspectors}

Administrative challenges pose a serious stress to teachers especially from the inspectors 
from ministry of education and the principals who according to some of the teachers are like 'lords'. This strong administrative hierarchy with a lack of support as perceived by the teachers causes stress. The teachers interviewed asserted that it was unfair to compel a teacher to adopt a particular method in teaching students as it has been observed that there are a lot of peculiarities among students. On Target setting and meeting targets, Principals are under pressure from the ministry to ensure the students perform well. The Principals in turn put pressure on the teachers to do all they can to make the students pass. Furthermore, erratic and sporadic inspections from school administrators and inspectors from the ministry of education put both the principal and teachers under pressure. Hence, teachers are given unrealistic mandates to ensure students pass examinations at all cost.

\subsection{Professional Skills}

Teaching is a dynamic occupation as the world we live in is changing with a fast pace. A lot of changes have been made on the curriculum to cope with the prevailing situation thereby enlarging the curriculum without enriching it as the case may be. Some of the teachers are still in the word of 'analog' while their counterparts in standard secondary schools have gone 'digital'. This can pose a serious threat to teachers who feel out of place with current advancements. Also, a teacher who is not adequately informed might have problems with the technicality of lesson plans and notes to write overnight. Another major cause of stress is able to adapt to changes in information and technology (ICT). As such some of them have gone back to acquire more training through sandwich programmes. It has been observed that sandwich is inadequate training and continuing education programme due to the nature of the programme. A whole year's work is compressed within few weeks.

\subsection{Parents/Teachers Relationship}

Parents' expectations of what teachers are supposed to do exceed the limit. If a child's performance academically or morally is poor, parents put the blame on the teachers. Meanwhile, the teachers have argued that there is decrease in parent/guardian's participation in student's academic work, increase in teacher's role in school and constant changes and new demands regarding roles of the teacher and taking more responsibility for all that happens to a student. It has been observed by teachers that some parents are not aware of homework and assignments given to their child/ward it is very late.

\subsection{Work- Life Pressure}

Ideally, teachers apart from the teaching job have their personal goals and ambitions. This strong administrative hierarchy with a lack of support as perceived by the teachers causes stress.

After a strenuous time in school may have difficulty in achieving their personal goals. The imbalance between school goals and their personal goals causes stress. Other challenges are the teachers' perception that they efforts are not recognized both in the school and the society.

\subsection{Environmental Factors (School)}

This includes poor sanitation and toilet system, stuffy classrooms, bad behaviour from 
students who feel they must pass at all cost.

\section{Signs and Symptoms of Stress on Teachers}

This study revealed that teachers interviewed are of the opinion that stress at work resulted to: Headache, high blood pressure, Mood swing, running stomach, toilet/bacterial infection, vomiting, loss of appetite, nervousness, back pain, Nausea, ulcer, muscular pain, tensed, loss of sex drive, fatigue, sleep problems, shouting, depression, anger, irritable, low morale, lack of concentration, lack of job satisfaction, fear, anxiety, loss of self-confidence, loss of sex drive, psycho-social pressure, sleep problem, and emotional problems among others. At the long run, teachers interviewed believed that some of the health challenges like high blood pressure some of them are facing are as a result of work-related stress.

\section{Consequences of Stress}

This study examined different stressors and found out that consequences of stress among teachers were behavioural, psychological, or physiological. These consequences according to the teachers interviewed have negative connotations. The assertion is that a teacher under stress will not be able to perform optimally both in the work place and at home. This study found that $87.3 \%$ opined that increasing levels of stress had adverse effect on their health. They believe that reduction of stress for them will help improve their performance. similarly, a survey of teachers in 2013 by financial services provider Teachers' Assurance revealed that stress levels within the teaching profession were affecting the ability of teachers to successfully perform their roles. Fifty six per cent said they would definitely be better at their job if they were less stressed, while 51 per cent admitted to 'severe' levels of work-related stress. Furthermore, the survey found that classroom teachers were more likely to feel the repercussions of stress than those in middle or senior management roles.

Apart from performance, stress negatively affected job satisfaction of teachers in the schools interviewed. This finding correlates to that of Fisher (2011) in a study on factors influencing stress, burnout and retention of secondary teachers where it was observed that stress is a statistically significant predictor of job satisfaction.

\section{Stress Prevention and Management}

Stress is pervasive and embedded in every facet of life. The complexities of life, climatic changes and dynamic nature of environment have made stress inevitable. Health and Safety Executive (2014) report reveals that Stress can cause changes in those experiencing it. Therefore, the major concern should be how to prevent or at least manage stress to the barest minimum. In some cases, there are clear signs that people are experiencing stress at work and if these can be identified early, action can be taken before the pressure becomes a problem. This may make it easier to reduce and eliminate the causes (Health and Safety Executive 2014). However, this study argues that stress can only be managed and cannot be completely eradicated as a result of economic and political challenges, complexities of life, climatic changes and dynamic nature of environment. 


\section{Steps to Management of Teacher Stress}

Identify the stressors and the situations which aggravate them

$>$ Create urgency in the minds of teachers on the signs, symptoms and dangers of stress

$>$ Conduct regular seminars, talks, lectures and workshop on teachers' welfares including career progression,

$>$ Create enabling environment. Create a forum where teachers will be free to air their minds without fear of victimisation.

It was observed that some teachers do not know that they have a part to play in order to moderate the level of stress they experience by carrying out a routine health check, regular exercises and take out time to rest as most of them are involved in businesses after school time.

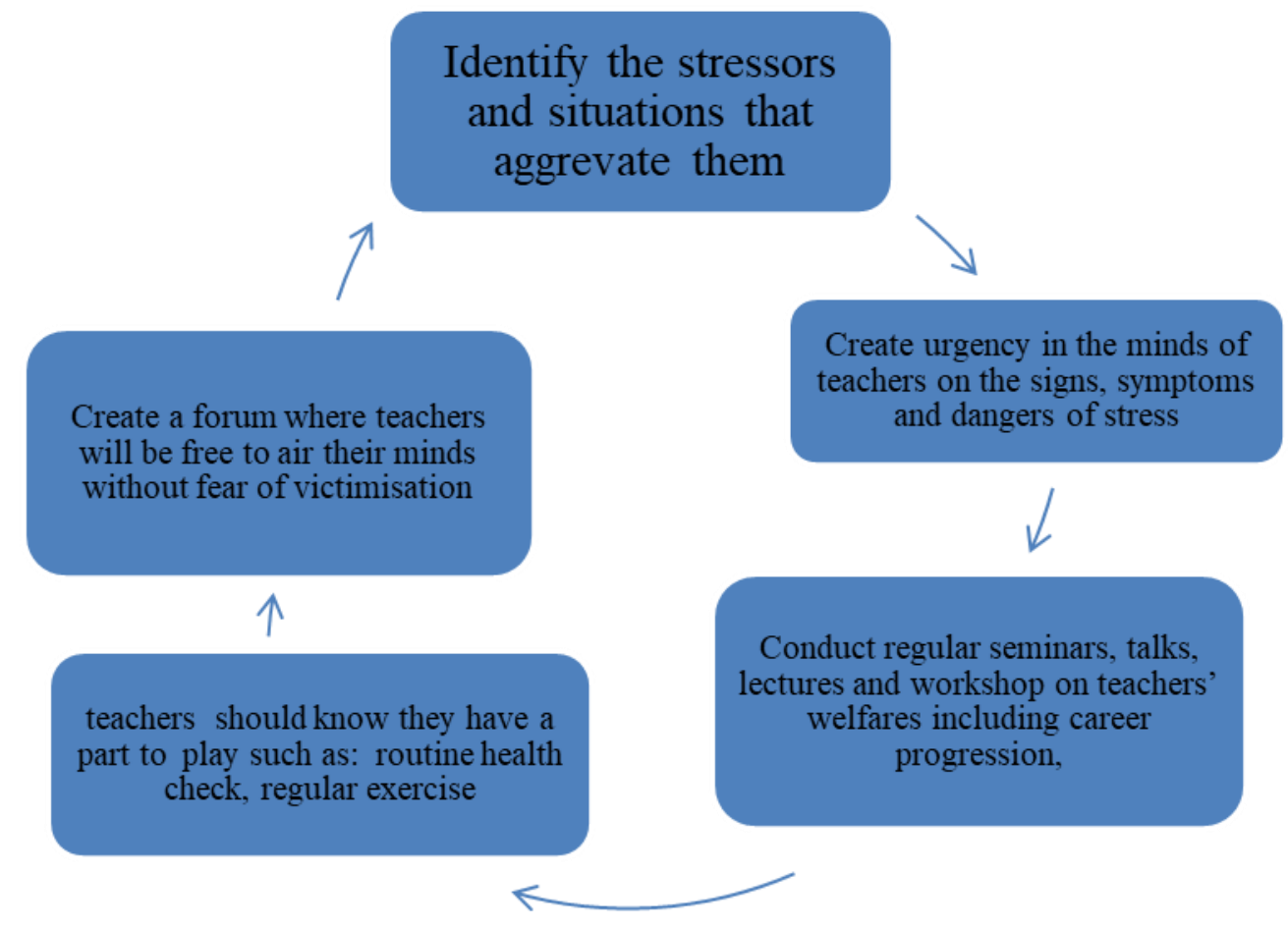

Figure 1. Steps to managing and reducing teacher stress

(Source: Field Survey 2018)

\section{Discussion on Findings}

It was revealed in this study that there is job related stress in the teaching profession. It was observed that more than $95 \%$ of the teachers interviewed perceive that teaching is a stressful profession. Others studies have stipulated that between $50 \%-100 \%$ posited that teaching profession is stressful (Bousted, 2013, Barabanshchikova, et al, 2014).

It was observed that there has been an influx of students into the public schools due to the 
current recession and economic hardship in the country without a relative increase in the number of qualified teachers and classrooms to accommodate the students. As such, the classrooms are over crowed and the workload excessive on the teachers. Moreover, this study revealed that major causes of stress among teachers are: Excessive workload due to largeness of the class and number of students per teacher. Apart from schools, there has been a great influx of people from areas affected by insurgents to Abuja. A greater number of them have settled in Abuja especially, in the suburban and metropolis. As at 2015, approximately 1.5million people from about 194,145 households from the north east of Nigeria comprising Adamawa, Bauchi, Borno, Gombe, Taraba, and Yobe (International Organization for Migration (IOM), 2015). According to United Nations report, Abuja grew at the rate of 139.7\% (between 2000-2010) making it the fastest growing nation (Boumphrey, 2010). As at 2016, Abuja population is estimated population at 6 million people (Jaiyeoba, 2016) as against 1,406,239 people in 2006 (Federal Capital Territory, 2015).

Ideally, as the number of households increased, the numbers of students enrolled in schools are expected to increase. Thus, there is increase in the teachers' workload in terms of academic and administrative work. Also, teachers are expected to prepare lesson plan for each class even if they had thought the lesson the previous year. Consequent upon this and the recession, there is an increase in the number of pupils who enrol into public schools. This is argued to be adversely affecting the teachers' ability to cope with. In handling the students, the teachers do not have control and autonomy on how best to teach their lesson knowing the peculiarity of each student and the class as a whole. Lastly, the schools under study do not have sufficient modern teaching materials, classrooms and computer laboratory.

Additionally, this study expounded some of the causes of stress among teachers as workload and class size per teacher, economic factors, government policies and programmes, professionalism, parent/teachers relationship, work-life pressures and environmental factors. Headache, nausea, lack of sex drive, High blood pressure, infections, nervousness, low morale, vomiting, lack of job satisfaction, back pain, chest pain, muscular pain, toilet infection, anxiety, sleep problem, unnecessary shouting, fatigue, anxiety, emotional problems among many are some of the signs of stress among teachers.

Manjula (2012) in a study on personality factors causing stress among school teachers showed that strict supervision, no good relationship with management and colleagues, lack of well-ventilated classrooms. Education International/European Trade Union Committee for Education Stress Report conducted a study on stress across all Central and Eastern European member organisations of Education International on, "The cause of stress for teachers, its effects, and suggested approaches to reduce it". Their study revealed Professional skills, Economic pressures, Strong administrative hierarchy with a lack of support, Poor planning and programming, difficult Parent/teachers relations, the school as a stressful workplace. There were similar to our findings.

Some researchers have reported that the secondary school teachers had a high level of stress and the difference in the level of stress reported by male and female teachers was significant with male teachers reporting higher level of stress than female teachers (Nwimo and 
Onwunaka, 2015, Aftab \& Khatoon, 2012) while others believe female teachers have higher level of stress than their male counterpart (Anbu, 2015, Kaur, 2008). According to Anbu (2015) female teachers apart from their official responsibilities are more involved in domestic chores.

Consequently, teaching as a profession is a demanding job that requires highly intellectual activities however, there are various intellectual symptoms of stress that can affect people in the profession, these includes memory problem, confusion, poor judgment, lack of concentration, while the emotional symptoms can be anger, irritation, being moody and depression, all of these can have negative adverse effects on the teachers' functionality (Morgan \& Kitching, 2007). Sir Gary Cooper study showed that constant changes in education policy added to teachers' stress levels (Wiggins, 2015) which was confirmed in our study.

Importantly, there is an aspect that has been downplayed and that is the place of being able to moderate one's level of stress, carry out a routine health check, do exercises and take out time to rest as most of them are involved in businesses after school time. American Psychology Association (2017) study on "Coping with stress" suggested the following steps in coping with stress: First, track your stressors: Take notes can help you find patterns among your stressors and your reactions to them. Second, develop healthy responses. Instead of attempting to fight stress with fast food or alcohol, do your best to make healthy choices when you feel a rise in tension. Exercise is a great stress-buster. Getting enough good-quality sleep is also important for effective stress management. Build healthy sleep habits by limiting your caffeine intake late in the day and minimizing stimulating activities, such as computer and television use, at night. Third, establish some work-life boundaries for yourself. Fourth, take time to recharge: to avoid the negative effects of chronic stress and burnout, we need time to replenish and return to our pre-stress level of functioning. This recovery process requires "switching off" from work by having periods of time when you are neither engaging in work-related activities, nor thinking about work. Don't let your vacation days go to waste. When possible, take time off to relax and unwind, so you come back to work feeling reinvigorated and ready to perform at your best. When you're not able to take time off, get a quick boost by turning off your smartphone and focusing your attention on non-work activities for a while. Fifth, learn how to relax. Sixth, talk to your supervisor. Healthy employees are typically more productive, so your boss has an incentive to create a work environment that promotes employee well-being. Start by having an open conversation with your supervisor. The purpose of this is not to lay out a list of complaints, but rather to come up with an effective plan for managing the stressors you've identified, so you can perform at your best on the job. While some parts of the plan may be designed to help you improve your skills in areas such as time management, other elements might include identifying employer-sponsored wellness resources you can tap into, clarifying what's expected of you, getting necessary resources or support from colleagues, enriching your job to include more challenging or meaningful tasks, or making changes to your physical workspace to make it more comfortable and reduce strain. Seventh, get some support. Accepting help from trusted friends and family members can improve your ability to manage stress. If you continue to feel overwhelmed by work stress, you may want to talk to a psychologist, who can help you better manage stress and change unhealthy behaviour. 


\section{Conclusion}

This paper has x-rayed the causes and consequences of stress among teachers in the junior secondary schools in Abuja. It was established that stress is the adverse psychological, physiological, behavioural and physical reactions that occur in an individual thereby causing a distortion of their stable state of equilibrium as a result of their being unable to cope with the demands being made on them. Stress in itself is not a disease but its aftermath can disarticulate the normal body equipoise that might lead to diseases. Stress among teachers in the junior category of secondary were caused by excessive workload and class size per teacher, economic factors, government policies and programmes, administrative pressure, changes in professional skills, parent/teachers relationship, work-life pressures and environmental factors. These factors had a negative effect on the teachers which led to back/muscular pains, stomach problem, high blood pressure, emotional imbalance, loss of appetite and sexual drive, lack of concentration among others. The aftermath of stress among teachers had psychological, physiological, physical and behavioural consequences. In conclusion, teachers have a part to play to ensure they maintain a healthy life style and moderate their level of stress. Therefore, we assert that a teacher under stress will not be able to perform optimally both in the work place and at home.

\section{Recommendations}

Stress though not a disease in itself has the pedigree to exasperate certain conditions that might permanently or temporarily tamper with one's health. When this is done an individual's optimal performance will be hampered. Consequently, serious attention has to be paid to issues that cause stress in an individual. Therefore, this study recommends that:

Government should employ more qualified teachers to cushion the effect of population explosion of students. The idea by the Present administration to employ teaching assistants that will be paid averagely, thirty thousand naira may cause more harm than good as some of those selected did not study education or related courses in the higher institution.

More classrooms should be built to cushion the effect of too many students in a classroom. Policy makers should involve at least a representative of all the main stakeholders in the educational sector before making any major policy. Also, Government should increase funding of the educational sector

Regular seminars on best practices, stress, well-being, career development and progression should be conducted regularly for teachers. Non Governmental Organisation NGO's should be encouraged to organise seminars on morals for students and Schools should have counselling who do not sit at the office waiting for salary at month end but one who help the students to be better citizens both at present and in future. This will help to educate teachers on how to handle stress and other issues of life. Also, there is need for a functional clinic in each school to take care of basic health care challenges. These clinics should have a qualified nurse and doctor. Also, basic health care delivery facilities (such as sphygmomanometer for regular blood pressures check) should be put in the school clinics.

Teachers should know that they have a part to play on how to handle stressors. They should 
be encouraged to carry out a routine health check, do exercises and take out time to rest, as most of them are involved in businesses after school time. Teachers should be given more autonomy on how to teach the students without removing the basic rudiments of teaching. Principals of schools with higher number of females than males should try as much as possible to avoid gender stereotype and at the same time be equitable in giving out work schedules. Besides, the principals should be careful to avoid over indulgence due to gender affiliation.

\section{References}

Aftab, M., \& Khatoon, T. (2012). Demographic Differences and Occupational Stress of Secondary School Teachers. European Scientific Journal, 8(5), 159-175.

Alan, H. S., Chan, K. C., \& Elaine, Y. L. C. (2010). Work Stress of Teachers from Primary and Secondary schools in Hong Kong. Proceedings of The International Multi-Conference of Engineers and Computer Scientists, III. 1-4.

American Institute on Stress "Transforming stress though awareness, education and collaboration" Retrieved from https://www.stress.org/stress-effects/ on 25/10/18

Anbu, A. (2015). Professional Stress of Higher Secondary School Teachers. International journal of Multidisciplinary Research and Development, 2(1), 1-3.

Barabanshchikova, V. V., Meshkova, P. R., Surova, D. N. (2014). Comparison of Stress Level among School Teachers in the Period of Organizational Changes, Procedia - Social and Behavioural Sciences, 146, 375 - 380. https://doi.org/10.1016/j.sbspro.2014.08.131

Baraza, O. T., Simatwa, E. M. W., \& Gogo, J. O. (2016). Levels of Stress among Secondary School Teachers and its Implication on Students' Academic Performance in Kenya: A Case Study of Kakamega North Sub County. Greener Journal of Educational Research, 6(2), 52-66. https://doi.org/10.15580/GJER.2016.2.032816069

Borg, M. J. (2010). Occupational Stress in British Educational Settings, Educational Psychology, 10, 103- 126. https://doi.org/10.1080/0144341900100201

Borman, W. C., \& Motowidlo, S. J. (1993). Expanding the Criterion Domain to Include Elements of Contextual Performance. In N. Schmitt \& W. Borman (Eds), Personnel Selection in Organizations, pp. 71-98. San Fransisco, CA: Jossey-Bass

Borman, W. C., \& Motowidlo, S. J. (1997). Task Performance and Contextual Performance: The Meaning for Personnel Selection Research. Human Performance, 10, 99-109. https://doi.org/10.1207/s15327043hup1002_3

Boumphrey, S. (2010). World's Fastest Growing Cities is in Asia and Africa. Retrieved from https://web.archive.org/web/20151117022953/http://blog.euromonitor.com/2010/03/special-r eport-worlds-fastest-growing-cities-are-in-asia-and-africa.html on 28/01/2017

Bousted, M (2013). Workplace Stress Among Teachers Must Be Taken Seriously. Retrieved from 
https://www.theguardian.com/teacher-network/teacher-blog/2013/jun/26/tackle-workplace-str ess-organisational-level on 7/1/2017

Cartwright, S., \& Cooper, C. L. (2002). ASSET: An Organisational Stress Screening Tool The Management Guide. Manchester: RCL Ltd.

Cherry, K. (2018). 5 Surprising ways that stress can affect your brain accessed from https://www.verywellmind.com/surprising-ways-that-stress-affects-your-brain-2795040

Cole, G. A. (2005). Personnel and Human Resource Management, 5th Edition, Padstow Cornwall T.J International.

Dlamini, C. S., Okeke, C. I., \& Mammen, K. J. (2014). An Investigation of Work-Related Stress Among High School Teachers in the Hhohho Region of Swaziland, Mediterranean Journal of Social Sciences, 5(15), 575 -586. https://doi.org/10.5901/mjss.2014.v5n15p575

Ekundayo, H. T., \& Kolawole, A. O. (2013). Stress among Secondary School Teachers in Ekiti State, Nigeria. Journal of Educational and Social Research, 3(2), 311-315. https://doi.org/10.5901/jesr.2013.v3n2p311

Federal Capital Territory. (2015). The population development in Federal Capital Territory, Retrieved from https://www.citypopulation.de/php/nigeria-admin.php?admlid=NGA015 on 28/01/2017

Fisher, M. H. (2011). Factors Influencing Stress, Burnout, and Retention of Secondary Teachers. Current Issues in Education, 14(1). Retrieved from http://cie.asu.edu/ on 7/1/2016

Ghkadmin. (2015). Stress Management. Retrieved from http://knowyourhealth.com.ng/2016/09/05/stress-management/ on 20/01/2017

Hamlett, C. (2016). How Stress Affects Your Work Performance, Retrieved from smallbuisnes.chron.com/stress-affects-your-work-performance-18040.html on 14/11/2016

Hanif, R. (2004).Teachers stress, job performance and self-efficiency of women school teachers, M. Phil Thesis, in National Institute of Psychology", Center of Excellence. Quaid-Azam University, Islamabad.

Health and Safety Executive. (2014), Signs and Symptoms of stress. retrieved on 14/11/2016 from www.hse.gov.uk/stress/furtheradvice/signsandsymptoms.html on 28/01/2017

Hellriegel, D., \& Slocum, J. W. (2010). Organizational Behaviour, USA: South Western Cengage Learning.

Hussain, H. (2010). A Study of Teacher Stress: Exploring Practitioner Research and Teacher Collaboration as A Way Forward, A thesis submitted in fulfilment of the requirements of Bournemouth University for the degree of Doctor of Professional Practice March 2010.

International Labour Organisation ILO (2012). The Encyclopaedia of Occupational Health and Safety, 4th Edition (online publications, Retrieved from http://www.iloencyclopedia.org on $15 / 09 / 2016$ 
International Organization for Migration IOM (2015). Retrieved from http://nigeria.iom.int/over-14-million-now-displaced-six-states-northeast-nigeria on $28 / 01 / 2017$

Jain, G., Tyagi, H. K, \& Kumar, A. (2015). Psycho-Social Factors Causing Stress: A Study of Teacher Educators. Journal of Education and Practice, 6(4) 125-130.

Jaiyeoba, A. (2016). FCT Minister Harps on Development of Satellite Towns. Retrieved from http://www.thisdaylive.com/index.php/2016/03/29/fct-minister-harps-on-development-of-satel lite-towns/ on 28/01/2017

Jarvis, M. (2002). Teacher stress: A critical review of recent findings and suggestions for future research. Retrieved from http://www.isma.org.uk/stressnw/teachstress1.htm on $23 / 12 / 2016$

Jehangir, M., Kareem, \& Tahir, M. et al (2011). Effects of Job Stress on Job Performance and Job Satisfaction, Interdisciplinary Journal of Contemporary Research in Business, 3(7).

Jitendar, S. N, Bhanu, P. S. N., \& Jitendar, S. (2016). A Conceptual Study on Occupational Stress (Job Stress/Work Stress) and its Impacts, Int. Journal of Advanced Research and Innovative Idea in Education, 2(1), 47-56.

Johnson, S., Copper, C., \& Cartwright, S. et al (2005). The Experience of Work-related Stress Across Occupations, Journal of Managerial Practice, 20(2), 178-187. https://doi.org/10.1108/02683940510579803

Kaur, S. (2008). Occupational Stress in Relation to Teacher Effectiveness among Secondary School Teachers, EduTracks, 7(10), 22-29

Kyriacou, C. (2001). Teacher stress: Directions for future research. Educational Review, 53(1), 27-35. https://doi.org/10.1080/00131910120033628

Manabete, S. S., John, C. A., Makinde, A. A., \& Duwa, S. T. (2016). Job Stress among School Administrators' and Teachers in Nigerian Secondary Schools and Technical Colleges. International Journal of Education, Learning and Development, 4(2), 1-9.

Manjula, C. M. A. (2012). A study on Personality Factors Causing Stress among Secondary School Teachers, Strength for Today and Bright Hope for Tomorrow, 12(2).

Marquet, D. (2016). Leadership nudge: Stress Performance Curve, Retrieved from www.davidmarquet.com on 06/12/2016

McCraty, R., \& Rees, R. A. (2009). The Central Role of the Heart in Generating and Sustaining Positive Emotions. In C. R. Snyder \& S. J. Lopez (Eds.), The Oxford Hand Book of Positive Psychology, pp. 527-534. Oxford, UK: OUP.

McDevitt, J. (2011). Teacher suicide rate rises by 80 per cent. Retrieved from https://www.channel4.com/news/teachers-suicide-rates-double-in-a-year on 14/01/2017

McEvoy, M. (2011). Stress is both External and Internal: How to Limit Stress to Improve 
https://metabolichealing.com/stress-is-both-external-internal-how-to-improve-your-health/ on $13 / 11 / 2016$

McIntyre, S. (2015). Using ecological momentary assessment to study job stress in middle school teachers, American Psychological Association 2012 Annual Conference, Aug 2-5, Orlando, Florida.

Merajver-Kurlat, M. (2009). Living with Stress, New York: Jorge Pinto Books Inc, PP.23-54

Moorhead, G., \& Griffin, R. (2004). Organisational Behaviour: Managing People and Organisations. 7th Edition. Boston, MA: Houghton Mifflin.

Morgan, M., \& Kitching, K. (2007). Teaching in Disadvantaged Schools: Job Satisfaction of Beginning Teachers, in Gillian, A. L. and Downes, P. (Eds.), Educational Disadvantage in Ireland. Dublin: Institute of Public Administration pp. 367-378.

Moss, C. A. (2008) Power of the Five Elements: Path to Healthy Aging and Stress Resistance. Retrieved from http://northatindiabook s, wordpress.com on 13/11/2016

Nadu, T. (2008), Teacher is the backbone of educational system: VC Retrieved from www.hindu.com/.../Teacher-is-the-backbone-of-educational-system-Vc/ on 26/12/2016

Nagel, L., \& Brown, S. (2003). The ABCs of Managing Teacher Stress, The Clearing House. 76(5), 255-258. https://doi.org/10.1080/00098650309602015

Naidoo, K., Botha, C. J., \& Bisschoff, C. A. (2013). Causes of Stress in Public Schools and its Impact on Work Performance of Educators, Journal of Social Science, 34(2) 177-190.

National Institute for Occupational Safety and Health (NIOSH) Stress at Work DHHS (NIOSH) Publication Number 99-101 Retrieved from http://wwwn.cdc.gov/pubs/niosh.aspx on $02 / 09 / 2016$

National Union of Teachers (NUT) (2016) NUT Health and Safety Briefing: Teacher Stress, December 2016 Retrieved from https://www.teachers.org.uk/help-and-advice/health-and-safety/t/tackling-teacher-stress on $14 / 01 / 2017$

Nixon, P (2007), Stress: The Human function curve. Retrieved from www.stress.org on 2/1/2017.

Nwimo, I. O., \& Onwunaka, C. (2015) Stress among Secondary School Teachers in Ebonyi State, Nigeria: Suggested Interventions in the Worksite Milleu, Journal of Education and Practice, 6(26), 93-100.

Nwosu, J. C., \& Ayodele, K. O. (2011). Predictors of Job Stress among Secondary School Teachers in Ogun State, Nigeria, Nigerian Journal of Parasitology, 32(1), 123-127.

Olusegun, A. J., Oluwasayo, A. J., \& Olawoyim, O. (2014). An Overview of The Effects of Job Stress On Employees Performance in Nigeria Tertiary Hospitals, Ekonomika, 60(4), 139-153. 


\section{Macrothink}

International Journal of Human Resource Studies

ISSN 2162-3058 2019, Vol. 9, No. 1

Omolara, B. E. (2008) Influence of work related stress on organizational commitment at Olabisionabanjo University Ago Iwoye Ogun State Nigeria. EABR \& TLC Conferences Proceedings. Rothenberg, Germany

Palmer, S. (2006). Rehabilitation After an Acute Episode of Work-Related Stress: A Case Study by an Anonymous Civil Servant. From (Retrieved on 10 April 2013)

Pandey, A. K. (2015). A Study of Occupational Stress between Government and Private School Physical Education Teachers, International Multidisciplinary Research Journal: Golden Research Thoughts; pp. 1-5

Parray, W. M, Kumar, S., \& Awasthi, P. (2016). Stress Among Teachers: A Theoretical Examination, International Journal of Indian Psychology; 3(4), No. 57.

Precey, M. (2015). Teachers stress in England Soaring High. Retrieved from https://www.bbc.com/news/education-31921457

Reddy, G. L., \& Anuradha, R. V. (2013). Occupational Stress of Higher Secondary Teachers Working in Vellore District. International Journal of Educational Planning and Administration, 3(1), 9-24.

Robert-Bullock, M. A. (2013). Job Performance Defined, Retrieved from www.consultingcafe.com/articles/job-performance-defined, on 07/11/2016

Sanders, R. (2013). Researchers find out why some stress is good for you, Retrieved from news.berkeley.edu/2013/04/16/researchers-finf-out-why-stress-is-good-for-you/ on $15 / 11 / 2016$

Segal, J., Smith, M., Robinson, L., \& Segal, M. A. (2016). Stress in the Workplace: Practical tips for dealing with job and workplace stress, Retrieved from www.helpguide.org/articles/stress/stress-at-work.htm on 06/12/2016

Sprenger, J. (2011) Stress and Coping Behaviours Among Primary School Teacher, Being A Thesis Presented To the Faculty of the Department of Health Education and Promotion, East Carolina University, In Partial Fulfillment of the Requirements for the Degree Master of Arts

Uchendu, U. I., \& Ukonu, O. I. (2016) Effect of Substance Use on Academic Performance among Students In The University Of Abuja, Nigeria Journal of Research in Humanities and Social Science, 4(30), $62-71$.

Ukonu, O. I., \& Tafamel, A. E. (2011), Occupational Health and Safety in Nigerian Public Sector: Annals of Humanities \& Development Studies, 2(2), 147-161.

UNESCO (2010). National Education Support Strategy (UNES) for the Republic of Kenya, 2010- 2011.

Wangui, M. F, Ombui, K., \& Iravo, M. (2016). Effects of Work-Related Stress on Teachers Performance in Public Secondary Schools in Kikuyu Sub County, Kenya, International Journal of Science and Research, 1645-1652. 


\section{Macrothink}

International Journal of Human Resource Studies

ISSN 2162-3058 2019, Vol. 9, No. 1

Wiggins, K. (2015). Teaching is Among the Top Three Most Stressed Occupation. Retrieved from

https://www.tes.com/news/school-news/breaking-news/teaching-among-top-three-most-stress ed-occupations on 14/01/2017

Will, M. (2017). Educators are more stressed at work than average people, survey Finds Retrieved

from https://blogs.edweek.org/teachers/teaching_now/2017/10/educator_stress_aft_bat.html

World Health Organization (2015). Stress at Work, Retrieved from www.who.int on 15/09/2016.

\section{Copyright Disclaimer}

Copyright for this article is retained by the author(s), with first publication rights granted to the journal.

This is an open-access article distributed under the terms and conditions of the Creative Commons Attribution license (http://creativecommons.org/licenses/by/4.0/). 